\title{
Fjernt og tæt på: Telemedicinens forskellige facetter
}

\section{Claus Bossen \& Stinne Aaløkke Ballegaard}

Aarhus Universitet

KORA

imvcb@dac.au.dk

StBa@kora.dk

Bossen, C \& Ballegaard, S.A. (2014). Fjernt og tæt på: Telemedicinens forskellige facetter. Tidsskrift for Forskning i Sygdom og Samfund, nr. 21, 5-13

Tv-serien "The Knick" foregår på Knickerbocker Hospitalet i New York i begyndelsen af 1900-tallet og har den kokain-brugende, ambitiøse kirurg John W. Thackery som omdrejningspunkt. Et afgørende vendepunkt $\mathrm{i}$ hans forhold til den fremragende, men desværre Harvard-, europæisk-uddannede og sorte kirurg Dr. Algernon Edwards kommer, da Thackery opdager, at Edwards har opfundet nye, nyttige teknologier i kælderen. Ny teknologi er lige, hvad den grænsesøgende, nyskabende Thackery har behov for for at kunne udføre nye operationer såsom kejsersnit. En anden lille episode er installeringen af elektricitet, hvorved glødepærer og små elmotorer afløser gaslamper og håndholddrevne pumper i forhold til opgaverne med at oplyse operationsstuen og suge blod og andre væsker bort fra operationssåret. 'Tv' betyder som bekendt tele-vision, og disse små episoder i de store fortællinger viser emblematisk, hvorledes medicin som felt historisk er præget af teknologiske landvindinger. Opfindelsen af stetoskopet, røntgen, dialyse, respiratoren, patientjournalen m.m. har afgørende ændret mulighederne for diagnostik, behandling og pleje og dermed også læge-patient forholdet (Reiser 2009). De vidensmæssige og teknologiske ressourcer, som disse teknologier kræ- 
ver, har samtidig fremmet en dynamik af stadig større specialisering og centralisering af hospitaler (Vallgårda 1992), som bl.a. betyder, at nogle borgere har langt til nærmeste hospital. Et problem, der med ironisk tvist søges løst gennem mere ny teknologi såsom telemedicin.

Fortællinger og visioner om teknologiers potentialer er et centralt karakteristika ved de moderne samfund siden 1800-tallet. De forløser angiveligt samfund fra deres vegetative stadier og udløser en forandring, der går 'fremad' og 'opad' mod noget bedre. Disse fortællinger spiller en central rolle for vores forståelse af udviklingerne i vore samfund generelt og indenfor sundhed, behandling og pleje mere specifikt. Indløses visionen ikke i den nære, så i det mindste i en fjern frem(ad) tid. I de store brede historiske fortællinger kan der være en tendens til at betone, hvorledes teknologier har drevet samfundsudviklingen frem: f.eks. hjulet, alfabetet og det skrevne ord, trykkekunsten, elektricitet og internettet. Kun med de store historiske penselstrøg lader det sig gøre at opretholde en fortælling om teknologidreven udvikling. Når man går i detaljer viser studier af, hvorledes teknologier er udviklet og taget i brug, at deres levedygtighed og gennemslagskraft er afgørende formet af udvikling af f.eks. kompetencer, viden og organisationsformer, der bærer dem. I disse små historier viser det sig, at teknologi-determinisme ikke holder, og at vi i stedet må fokusere på, hvorledes teknologi, praksis og organisering gensidigt former hinanden (Misa 1988) (Huniche and Olesen 2014). I parentes bemærket bør det nok, for ikke at gøre tv-branchens fortællinger om medicinen som felt uret, nævnes, at en anden tv-serie, "Grey's Anatomi" (Greys Hvide Verden), har en gruppe af læger som hovedpersoner og fokuserer i højere grad på det kirurgiske håndværk og evnen til at kunne samarbejde under pres trods interpersonelle konflikter. En tredje populær serie, "House", har den mentalt geniale, men fysisk svækkede læge af samme navn som hovedperson og fokuserer på højt specialiseret ekspertviden og evnen til at diagnosticere vanskelige tilfælde.

Som udgangspunkt er begrebet telemedicin indifferent overfor teknologi. Begrebet betyder blot medicin-over-afstand. Men i dag er telemedicin næsten blevet synonymt med de nye muligheder for diagnostik, behandling og pleje, der angiveligt potentielt ligger i informations- og kommunikation teknologi video-links, elektronisk udveksling af data ml. hjem, praktiserende læge, sundhedscentre og hospitaler og online monitorering af patienter. En kort definition lyder således, at telemedicin er »digitalt understøttede sundhedsfaglige ydelser over afstand« (Dansk Selskab for Klinisk Telemedicin: www.dskt.dk). En anden mere detaljeret definition lyder: "Begrebet telemedicin dækker over forskellige typer digitalt understøttede sundhedsydelser. Ved hjælp af borgeres oplysninger om eget helbred, 
via video, billeder, spørgeskemaer og måleresultater som f.eks. blodtryk, vægt, glukosetal og iltmætning i blodet, kan medarbejdere i sundhedsvæsenet følge, diagnosticere, behandle og rådgive om sygdomme hos borgere, mens de opholder sig i deres eget hjem. Borgerne får værktøjer til at følge eget helbred og kan blive bedre til at mestre egen sygdom, ligesom de slipper for at skulle ind på hospitalet." (Region Midt, Danmark, Center for Telemedicin) .

Begrebsmæssig er telemedicin dog ikke nødvendigvis digital, men kan betegne enhver form for sundhedsydelse, der sker over afstand. I denne forstand praktiseredes allerede $i$ antikken telemedicin via signaler med røg og flag, der skulle advare udefrakommende om udbrud af sygdom og smittefare, postordre-behandling $i$ 1600-tallet, fremsendelse af urter i små poser og konsultationer per telegraf eller telefon. Telemedicin er således tæt forbundet med mulighederne for at kommunikere (Langstrup 2013). Men dels kan telemedicin nemt give associationer til de nu forældede teknologier (fastnet)telefonen og -grafen, dels er IT i dag den mest udbredte kommunikationsinfrastruktur. 'Tele' har således mistet sit visionære element. Der sker derfor ofte en glidning, således at medicin-på-afstand defineres på basis af de allestedsnærværende og ofte integrerede digitale teknologier (video, email, chat, audio) som eSundhed (eHealth). Hermed får fænomenet et teknologisk udgangspunkt, samtidig med at det breder begrebet ud til at omfatte 'sundhed' i en mere bred forstand end den rent 'medicinske'. Telemedicin bliver til en fortælling om teknologi som i The Knick, snarere end om samarbejde og ekspertviden som i henh. Grey's Anatomi eller House.

Visioner om teknologi ledsages oftest af såvel utopiske som dystopiske forventninger og forestillinger om, hvordan de vil forme fremtiden. Dette kan føres helt tilbage til Sokrates' kritik af alfabetet og skriftsproget, som han argumenterede for ville ødelægge evnen til at huske og gøre det muligt for folk at fremføre viden, de ikke i tilstrækkelig grad havde internaliseret. På samme måde blev telefonens udbredelse fulgt af kritik for at udhule sociale relation og føre til overfladisk konversation, og internettet i 1990erne kritiseret for at føre til cyber-affærer, utroskab og udhuling af 'virkelige ' i betydningen ansigt-til-ansigt relationer (Baym 2010).

Visionerne, der knyttes til telemedicin er mange: muliggøre behandling af borgere, som har langt til nærmeste hospital eller læge som f.eks. i Norge, Canada eller Australien, spare patienter for transporttid til hospitaler og praktiserende læger, føre til hurtigere udskrivning og dermed spare hospitalssenge, muliggøre hyppigere eller ligefrem kontinuerlig kontrol, o.s.v. Mere samfundsorienteret ses telemedicin som en nødvendighed for at imødegå de stigende omkostninger indenfor sundhedssektoren pga. stadig mere avancerede behandlingsformer og en 
stigende andel ældre, som antages at have behov for flere sundhedsydelser på trods af, at ældre i dag har bedre helbred end for en generation siden (Se f.eks. de nyeste strategier for sundhed og telemedicin fra kommunerne, regionerne og regeringen i Danmark ). Det hedder således med en typisk formulering, "'Med telemedicinske løsninger bliver det muligt at drive sundhedsvæsenet på nye måder. Og udsigten til flere ældre, flere mennesker med kroniske sygdomme og et begrænset økonomisk råderum betyder, at der er behov for nytænkning" (Regeringen, KL og Danske Regioner 2013, s6). At de stigende omkostninger og flere ældre bl.a. er et problem, der skyldes, at nye teknologier har betydet længere levetid og ressourcekrævende specialiseringer og behandlinger, og som så skal løses via mere teknologi, er igen et ironisk tvist. Men nye teknologier har som oftest ironiske eller paradoksale konsekvenser (Arnold 2003).

De mere dystopiske udsigter, som knyttes til telemedicin, drejer sig om spørgsmål som f.eks. flg.: Vil forholdet mellem patienten og den sundhedsprofessionelle udhules eller helt erstattes af automatisk indberetning og monitorering? Vil patienter blive udskrevet for tidligt og blive overladt til sig selv hjemme? Bliver omsorg erstattet af teknologi? Betyder 'tele' i praksis ikke 'over afstand', men 'fjern!'medicinen?

Disse utopiske og dystopiske visioner fremføres ikke kun i Danmark, men også i vore nabolande Norge og Sverige og mere generelt Europa, Amerika og andre steder med flere ældre og stigende udgifter til sundhedssektoren. De hidtidige erfaringer er endnu i bedste fald blandede. I forhold til relationerne ml. patient-borger og de sundhedsprofessionelle, viser hidtidige erfaringer, at telemedicin ikke blot er en ny teknologi til understøttelse af behandling og pleje, men betyder en anden slags behandling og pleje. Forholdet ml. sundhedsprofessionelle, patienter og disses respektive roller og ansvar forandres. Læger og sygeplejersker skal lære at tolke data og bedømme relevant behandling og pleje ud fra video og tale, men uden den adgang til at læse patienters krop og adfærd som ansigt-til-ansigt møder giver. Begreber som 'fjerne læger' og 'fraværende patienter' er lanceret for at beskrive aktørerne i de it-medierede konsultationer (Mort, May et al. 2003), mens begreber om 'fysisk nærhed' og 'digital nærhed' forsøger at beskrive den samtidige forøgelse og forkortelse distance, telemedicinen indebærer (Oudshoorn 2009). Teknologierne forstærker nogle indtryk og formindsker andre: Konsultation via web-kamera giver indblik i patientens hjem, men kun visuelt og auditivt og ikke duft- og fugtighedsmæssigt. Sygeplejersken bliver gæst i borgerens stue, borgeren bliver patient i klinikken (Pols 2012). Patienter skal lære selv at betjene teknologier i hjemmet, tage ansvar for regelmæssige målinger, indsende data m.m. De bliver 
'diagnostiske agenter' eller 'patient 2.0' med de nye ansvar, muligheder og risici dette giver (Oudshoorn 2008) (Olesen 2010; Danholt, Piras et al. 2013).

Samtidig er såvel den kliniske evidens for bedre behandling og de økonomiske effekter endnu ikke afklarede. Det hænger bl.a. sammen med at udviklingen af nye teknologier - processen fra ide over prototype og pilotforsøg til faktisk ibrugtagning og drift - kan være langstrakt. De første implementeringer af telemedicinske løsninger hidtil har været rettet mod at undersøge, om og hvordan det kan lade sig gøre: Hvordan skal teknologien designes? Hvilke ændringer i arbejdsgange og organisation kræver det? Hvad er effekterne for sundhedsprofessionelle og patient-borgere? Af samme grund er der få undersøgelser af den kliniske evidens for, at telemedicin gør en forskel. Iflg. et review fra 2002 var der dengang ud af ca. 1.300 forsøg med telemedicin kun 5\%, der havde undersøgt den kliniske evidens (Hailey, Roine et al. 2002). Et review af 141 randomiserede studier af telemedicin med patienter med astma, KOL, diabetes, hjertesygdom eller hypertension viste, at telemedicin havde blandede resultater, at evidensen var svag og modstridende, samt at kun få studier havde beskæftiget sig med omkostningerne (Wootton 2012). Erfaringerne fra f.eks. Region Nordjyllands TeleKat-projekt (2010-11) viste for eksempel, at KOL-patienter, der indgik i det telemedicinske projekt havde signifikant færre indlæggelser end en tilsvarende gruppe patienter uden telemedicin, imens det er usikkert, hvorvidt det reducerede omkostningerne. Det konkluderes, at der formentlig kan høstes gevinster, men at det kræver en indsats i forhold til sammenspillet mellem teknologi, organisation og sundhedsprofessionelle (Dinesen, Haesum et al. 2012).

Det hidtil største og evidens-baserede forsøg med indførelse af telemedicin er gennemført i England i det såkaldte Whole System Demonstrator projekt (WSD) (2008-2012). Projektet omfatter analyse af data fra 3230 patienter og 179 læger i almen praksis i England med fokus på kroniske sygdomme, herunder diabetes, hjertesvigt og KOL. Resultaterne viste, at telemedicin reducerede dødelighed og akutindlæggelser på hospitaler, men ikke indebar nogen forskel i livskvalitet, ængstelse eller depressive symptomer i en sammenligning af telemedicinsk baserede og almindelige behandlingsforløb. Samtidig steg hospitalsomkostninger med 15\%. En konklusion var, at forudsætning for at telemedicin kan blive omkostningseffektiv, er, at teknologierne bliver billigere og drives i stor skala (For en opsummering af WSD og referencer hertil, se (Kidholm, Dinesen et al. 2014)).

Selvom erfaringerne er blandede i forhold til såvel klinisk evidens, reduktion af omkostninger og de nye roller og relationer, der er udkommet af telemedicin, har det ikke ændret på de forrige årtiers optimistiske og utopiske forventninger 
til telemedicinens potentialer. Man behøver blot læse de forskellige strategier, der er kommet de sidste år (Se fodnote 1).

Men hvad der tydeligvis er forandret, er at telemedicin nu har bevæget sig fra en ide- og prototype-fase til de spæde forsøg på storskala og daglig drift og brug i stedet for midlertidige projekter. Tidligere var der typisk tale om teknologiafprøvning - "kan vi få det til at virke?" - med fokus på en sektor og et behov eller én diagnose. Dette er nyligt suppleret med udvikling af tværsektorielle projekter med inddragelse af flere behov og flere diagnoser og opstarten på samarbejde på tværs af organisationer, ændrede arbejdsformer og undersøgelse af gevinster i storskala. I Danmark i dag (2014) igangsættes nationale projekter omkring f.eks. sårbehandling og tele-KOL ansporet af bl.a. den "National Strategi for telemedicin" (Regeringen, KL. og Danske Regioner 2012)(For et overblik over igangværende telemedicinske projekter, se (Kierkegaard 2014)). En anden forandring er anerkendelsen af, at teknologi ikke gør det alene. Teknologier har ikke en iboende kraft, der driver forandring fremad, men kræver et arbejde med mennesker, organisationer og videreudvikling af teknologien (Latour 1986). Spørgsmålet i dag er: "hvordan kan vi re-designe arbejdsgange, organisering og teknologi, så det arbejder sammen?" Hertil er der etableret centre i såvel Region Midt som Region Hovedstaden , og Regionsrådsformanden for Regions Midt udtaler, at " Telehealthcare is not just about technology. First of all, it is about people and organizations" . Ny teknologi kræver for at virke oparbejdelse af nye kompetencer, nye arbejdsgange og reorganisering ikke blot på hospitaler, lægepraksisser og sundhedscentre, men også i hjemmet (Ballegaard 2011). Netop her har ide- og prototype projekterne (også) deres berettigelse, idet de peger på de forskellige interesser, forandringer, barrierer og katalysatorer en ny teknologi møder. Hermed kan de pege på og fremme de forandringer, som er nødvendige for at nå frem til daglig drift og brug (Bossen 2007) (Winthereik 2010).

Telemedicin er dermed ved at udvikle sig fra projekter til infrastrukturer, og gode infrastrukturer er, som Bowker og Star skriver, vanskelige at finde. Dels fordi de er arbejdskrævende at opbygge og skal indlejre sig mellem allerede eksisterende infrastrukturer, hvilket kan kræve knudrede løsninger og skæve kompromiser. Dels fordi, at infrastrukturer bliver til kontekst og bliver usynlige, når først de kører gnidningsfrit (Bowker and Star 1999). Således var der engang noget, der hed tele-radiologi, hvilket i dag har mistet sit 'tele' præfiks, fordi det er helt almindeligt at sende røntgen- og andre billeder elektronisk. Med andre former for telemedicin er vi endnu i en brydningstid, hvor sundhedsprofessionelle, patienter og borgere skal yde en indsats for at få nye roller, ansvar, koordination og opgaver 
til at arbejde sammen (Langstrup 2013). I dag er dette arbejde endnu synligt, men forsvinder som kontekst, hvis telemedicinske projekter lykkedes og bliver svære at finde.

Dette temanummers fire artikler tager fat lige præcis her. Tre af artiklerne har udgangspunkt i Norge, der har været i gang med telemedicin siden 1990erne. Niels Kolstrups artikel "The Internet as a medium for delivering treatment for depression" opsummerer erfaringerne med og evidensen for anvendelsen af internettet som medium for behandling af depression. Artiklen fokuserer specifikt på 'internet cognitive behavioural therapy' og erfaringerne med det australsk udviklede MoodGYM, som er et online træningsprogram, der sigter mod at forebygge og bidrage til helbredelse af depression. Den viser således, hvorledes telemedicinske projekter er kommet forbi ide- og projektfasen og fokuserer på udvikling af teknologi og evidens. Kari Dyb \& Hege K. Andreassens artikel "Telemedisin: et maktperspektiv" analyserer ud fra to cases med indførelse af telemedicin til henh. hjertestop og dermatologi, hvorledes telemedicin indgår i interessekonflikter mellem mellem statslige styringsinteresser og professionel autonomi. Artiklen viser således, hvorledes ny teknologi er afhængig af og indgår i organisatoriske og professions-baserede interesser. Ingunn Moser \& Hilde Thygesens artikel "Prosjekteriets dilemma" argumenterer for, at det hidtidige fokus på kortvarige enkelt-projekter hindrer udveksling af erfaringer, læring på tværs af projekter og udvikling af længerevarende initiativer. Artiklen viser således nødvendigheden af, at telemedicin ikke længere alene beskæftiger sig med én diagnosegrupper og én sektor og i stedet arbejder på tværs og i stor skala. Endelig tager Tariq Andersens artikel "Designantropologiske undersøgelser af Patient 2.0" fat på den åbne, uafsluttede proces som udvikling af telemedicin er: Vi ved ikke præcist, hvordan telemedicin i hverdagsdrift kommer til at se ud, og hvilke nye patientroller, det indebærer. Han argumenterer for, at designantropologi, som kombinerer iterative design-processer med antropologiske studer af den samtidig forandring i sundhedspraksis, er specielt egnet til at udforske og udforme disse nye fremtider.

Alt i alt tager behandler disse artikler de problematikker, der opstår, når visionerne møder hverdagsbrugen i praksis. Deres fortællinger ligger måske tættere op Grey's Anatomy's fokus på samarbejde, konflikter og processen med at komme videre, snarere end den lægedrevne teknologiudvikling i The Knick eller den specialiserede, lægelige ekspertviden i House.

Udover disse fire artikler om telemedicin, har dette nummer af Tidsskrift for Forskning i Sygdom og Samfund en analyse af forebyggelseskampagner mod rygning i Danmark. Betina Verwohlt analyserer udviklingen af disse kampagner 
fra 1950 til 2010 og sammenligner dem med lignende kampagner i Sverige. Dette viser en tankevækkende forskel på hvilke fortællinger og motiver, der er fremherskende i de to lande i forhold til opfattelserne af statens og borgernes ansvar for at sikre en røgfri befolkning.

God fornøjelse med læsningen.

\section{Referencer}

Arnold, M. (2003). »On the phenomenology of technology: the "Janus-faces" of mobile phones.«Information and Organization 13(4): 231-256.

Ballegaard, S. A. (2011). Healthcare technology in the home. Of home patients, family caregivers, and $a$ vase of flowers. Aarhus. Available at: http://www.kora.dk/media/1735979/healthcare-technology-in-the-home-of-home-patients-family-caregivers-and-a-vase-of-flowers.pdf, Aarhus University.

Baym, N. (2010). Personal connections in the digital age. Malden, MA, Polity Press.

Bossen, C. (2007). »Test the artefact-Develop the organization: The implementation of an electronic medication plan. «nternational Journal of Medical Informatics 76(1): 13-21.

Bowker, G. C. and S. L. Star (1999). Sorting Things Out. Classification and Its Consequences. Cambridge (Mass) \& London, MIT Press.

Danholt, P., E. M. Piras, et al. (2013). »The Shaping of Patient 2.0: Exploring Agencies, Technologies and Discourses in New Healthcare Practices.« Science \& Technology Studies 26(2): 3-13.

Dinesen, B., L. K. Haesum, et al. (2012). »Using preventive home monitoring to reduce hospital admission rates and reduce costs: a case study of telehealth among chronic obstructive pulmonary disease patients. " Journal of Telemedicine and Telecare 18(4): 221-225.

Hailey, D., R. Roine, et al. (2002). „Systematic review of evidence for the benefits of telemedicine." Journal of Telemedicine and Telecare 14: 1-7.

Huniche, L. and F. Olesen (2014). Teknologiforståelse og sundhedspraksis. Teknologi i sundhedspraksis. F. Olesen and L. Huniche. København, Munksgaard: 35-60.

Kidholm, K., B. Dinesen, et al. (2014). »Behov for mere forskning i telemedicin til veldefinerede patientgrupper. « Ugeskrift for læger 176: 2-6.

Kierkegaard, P. (2014). »Mapping telemedicine efforts: surveying regional initiatives in Denmark. Telemedicine and e-Health.« Telemedicine and e-health 20.

Langstrup, H. (2013). Telemedicin. Teknologi i sundhedspraksis. L. Huniche and F. Olesen. København, Munksgaard: 215-240.

Latour, B. (1986). The Powers of Association. Power, Action, and Belief: A New Sociology of Knowledge? J. Law. London, Routledge: 264-280.

Misa, T. J. (1988). »How Machines Make History, and How Historians (and Others) Help Them to Do So.« Science, Technology \& Human Values 13(3\&4): 308-331.

Mort, M., C. R. May, et al. (2003). »Remote Doctors and Absent Patients: Acting at a Distance in Telemedicine?« Science, Technology, \& Human Values 28(2): 274-295. 
Olesen, F. (2010). Den forstærkede patient: Om patientbegreber og empowerment. Viden, virkning og virke: Forslag til forståelser $i$ sundhedspraksis. U. J. Jensen, M. Nissen and K. Thorgaard. København, Roskilde Universitetsforlag: 307-332.

Oudshoorn, N. (2008). »Diagnosis at a distance: the invisible work of patients and healthcare professionals in cardiac telemonitoring technology." Sociology of Health $\mathcal{E}$ Illness 30(2): 272-288.

Oudshoorn, N. (2009). »Physical and digital proximity: emerging ways of health care in face-to-face and telemonitoring of heart-failure patients.« Sociology of Health $\mathcal{E}$ Illness 31(3): 390-405.

Pols, J. (2012). Care at a Distance. On the Closeness of Technology. Amsterdam, Amsterdam University Press.

Reiser, S. J. (2009). Technological Medicine - The Changing world of Doctors and Patients Cambridge, Cambridge University Press.

Vallgårda, S. (1992). Sygehuse og sygehuspolitik i Danmark. Et bidrag til det specialiserede sygehusvæsens historie 1930-1987. København, Jurist- og Økonomforbundets Forlag.

Winthereik, B. R. V. I. (2010). »The Project Multiple: Enactments of systems development,.« Scandinavian Journal of Information Systems 22(2).

Wootton, R. (2012). »Twenty years of telemedicine in chronic disease management - an evidence synthesis.« Journal of Telemedicine and Telecare 18(4): 211-220. 